\title{
Cezary KOŚCIELNIAK
}

DOI : $10.14746 /$ pp.2018.23.1.13

\section{Szkolnictwo wyższe i dyplomacja naukowa jako narzędzie soft power w polityce ChRL wobec Unii Europejskiej}

\begin{abstract}
Streszczenie: Celem tekstu jest ukazanie kształtowania się chińskiego szkolnictwa wyższego, jako formy soft power. Chińskie szkolnictwo wyższe traktowane jest jako element soft power polityki międzynarodowej Chińskiej Republiki Ludowej. Wykorzystanie instrumentu, jakim jest polityka szkolnictwa wyższego w postaci soft power możliwe jest dzięki dynamicznemu rozwojowi chińskich uczelni w ostatnich dwóch dekadach. Władze ChRL stawiają przed swoimi uczelniami ambitne cele, m.in. wprowadzenie kilkunastu uczelni do ligi najlepszych uniwersytetów świata. Chińskie uczelnie odchodzą od wzorca kultury organizacyjnej „,copycat”, rozwijając własną dynamikę innowacyjności uczelni, poprzez konsekwentne podnoszenie swoich pozycji w międzynarodowych rankingach. Jednocześnie jednak cele rozwojowe stawiane chińskim uczelniom powiązane są z globalną ekspansją gospodarczą ChRL. Dyplomacja naukowa Państwa Środka działa przede wszystkim poprzez Instytuty Konfucjusza. Uczelnie Unii Europejskiej stanowią cel strategiczny w tej polityce, gdyż posiadają one zasoby i praktyki konieczne do wzmocnienia uczelni chińskich. Artykuł analizuje wybrane aspekty użycia polityki uczelnianej jako soft power chińskiej dyplomacji.
\end{abstract}

Słowa kluczowe: Uczelnie w Chinach, dyplomacja naukowa, soft power, Unia Europejska, polska polityka szkolnictwa wyższego

\section{Wstęp}

Władze Chińskiej Republiki Ludowej przeprowadzają gruntowne reformy szkolnictwa wyższego, które można nazwać „,rewolucją instytucji wiedzy”. Rozwój polityki uniwersyteckiej Państwa Środka zostaje powiązany z globalną ekspansją chińskiej gospodarki, gdzie polityka szkolnictwa wyższego jest wykorzystywana jako soft power przez chińską dyplomację. Celem niniejszego tekstu jest zarysowanie odpowiedzi na pytania: w jaki sposób rozwój szkolnictwa wyższego wpisuje się w globalną ekspansję gospodarczą Chin? W jaki sposób ChRL buduje dyplomację naukową, będącą formą soft power w polityce adresowanej do Unii Europejskiej? Wreszcie, jakie znaczenie może przynieść chińska dyplomacja naukowa polskiemu szkolnictwu wyższemu?

Zaangażowanie polityki szkolnictwa wyższego do działań na polu polityki międzynarodowej ChRL ma swoje uzasadnienie. Chiny stają się globalnym liderem w nowych dziedzinach, w tym także w produkcji publikacji naukowych, Tomaszewska (2015, s. 50-51) powiada tak: „Chiny od lat są największym eksporterem na świecie, liderem w produkcji energii słonecznej i wiatrowej, największym producentem złota, mają też największą liczbę doktoratów technicznych, coraz więcej patentów i publikacji naukowych [...]". Rozwój szkolnictwa wyższego jest powiązany z ekspansją naukowo-polityczną ChRL, zakładającą wejście uczelni Państwa Środka na rynek globalnej konkurencji międzyuczelnianej, co miałoby finalnie doprowadzić do wzmocnienia potencjału gospodarczego Chin. Zarówno 
doskonałość naukowa europejskich uczelni oraz intensywny rozwój wymiany handlowej - Chiny są drugim po USA największym partnerem handlowym dla Unii Europejskiej - generuje zapotrzebowanie na wykwalifikowaną kadrę potrzebną już nie tylko do obsługi tej wymiany jak to miało miejsce dotychczas, ale także procesów kreatywnych stosowanych we nowoczesnych dziedzinach gospodarki ${ }^{1}$. „Rewolucja naukowa”, przez którą Chiny aktualnie przechodzą jest poważną zmianą przejścia z polityki importu wiedzy i porzucenia kultury „,copy-paste”, na rzecz tworzenia własnych zasobów wiedzy i technologii oraz rozwoju sprawnych instytucji wiedzy do tego przeznaczonych. Realizacja tego celu wymaga sprzężenia ze sobą dwóch czynników: zwiększenia internacjonalizacji akademickiej oraz możliwie najściślejszego uwspólnienia celów badawczych i edukacyjnych z gospodarczymi. Chiny nie dysponują na tyle wystarczającym potencjałem akademickim by móc uniezależnić swoje uczelnie od rynku międzynarodowego, stąd też naczelnym zadaniem intensywnej ekspansji dyplomacji naukowej jest zbudowanie systemu instytucji wiedzy opierającej się o własne zasoby.

\section{Wybrane aspekty przemian chińskiego szkolnictwa wyższego}

W ostatnich dwóch dekadach chińskie szkolnictwo wyższe przechodzi przez proces, który można nazwać „,rewolucją naukową”. Szkolnictwo wyższe Państwa Środka w całości zależy od polityki rządu i pozostaje pod jego nadzorem, niemalże wszystkie uczelnie są publiczne. Wskazując na kilka kluczowych informacji faktograficznych: według danych rządu chińskiego w roku 2014 funkcjonowało 2542 uniwersytetów i instytucji szkolnictwa wyższego dzielących się ze względu na podległość ministerstwu edukacji, innym ministerstwom (w zależności od charakteru szkół), ale także prowincjom oraz miastom (Ministerstwo Edukacji ChRL, 2014). W roku 2015 funkcjonowało 734 tak zwanych „nie rządowych instytucji szkolnictwa wyższego", (Ministerstwo Edukacji ChRL, 2015). W ostatnich dwóch dekadach chińskie szkolnictwo wszystkich szczebli, w tym także szkolnictwo wyższe, przechodzi przez bardzo silne przemiany, charakteryzujące się m.in. zwiększeniem liczby uczących się, czy otwarciem się na umiędzynarodowienie kształcenia ${ }^{2}$.

Jednym z najważniejszych czynników zmiany jest bardzo silnym trend wzrostu enrolment rate. Dynamika tego procesu jest wysoka - w ciagu pięciu lat wynosi ona aż $10 \%$. Pośrednio wynika to z sytuacji charakterystycznej dla państw transformacyjnych, w których ilość studentów zazwyczaj jest niższa niż w państwach wysokorozwiniętych. W rankingu OECD, w kategorii w grupie wiekowej 25-65 osób z wyższym wykształceniem Chiny znajdują się na przedostatnim miejscu: w 2015 roku, liczba osób z wyższym wykształceniem nie przekroczyła $10 \%$ średniej OECD, daje to przedostatnią pozycję

${ }^{1}$ Por. Sporek (2012) analizując relacje handlowe między UE a ChRL w pierwszej dekadzie XXI wieku wskazuje na dialog sektorowy w dziedzinach takich jak: środowisko, energia, komunikacja społeczna, polityka przemysłowa. Wskazuje również na dramatyczny wzrost wymiany handlowej: „W latach 2000-2010 wartość wymiany handlowej Unii Europejskiej z ChRL została potrojona, natomiast udział Chin w handlu Wspólnotowym w tych latach podwoił się" (s. 38). Szwabe (2005), analizuje bieżące problemy wymiany gospodarczej między UE a ChRL.

2 Analiza historyczna przemian chińskiego szkolnictwa wyższego, zob. Schulte, 2012. 
przed Indonezją (zob. OECD, 2017, fig. A1.4, s. 37). Natomiast enrolment rate w grupie wiekowej 20-24 lata w roku 2014 wyniósł około 15\% średniej OECD (OECD, 2017, fig. C1.2, s. 285).

Pierwszy etap chińskiej „rewolucji naukowej” nastąpił w roku 1999, kiedy to rząd zdecydował się na zbudowanie masowego kształcenia na poziomie trzeciego stopnia. Staplenton (2017) tak komentuje tę zmianę: ,[...] Dwadzieścia lat temu szkolnictwo wyższe w Chinach było rzadkim przywilejem, którym cieszyły się małe, miejskie elity. Ale wszystko zmieniło się w 1999 r., gdy rząd rozpoczął program masowych przyjęć studentów na uniwersytet. $\mathrm{W}$ tym samym roku uczelnie przyjęły o 50\% więcej kandydatów, a średnia roczna stopa wzrostu utrzymała się przez kolejne 15 lat [...]".

Autorka wskazuje, że w 2003 roku liczba przyjętych studentów w Chinach zrównała się z USA i wynosiła 3 miliony. W 2013 r. liczba ta wynosiła już 7 milionów (OECD, 2017).

W odróżnieniu od europejskiego systemu edukacyjnego podzielonego na trzy poziomy kształcenia: licencjacki, magisterski i doktorski, system chiński posiada jeszcze jeden poziom - czy raczej formułę kształcenia - określoną przez OECD jako „short cycle tertiary”. System ten jest skróconą i niepełną formą studiów posiadającą certyfikację, niewątpliwie jest to najtańsza forma studiów i dająca możliwość szybkiego transferu z edukacji do rynku pracy. W 2015 roku z 6808866 absolwentów publicznych szkół wyższych kształcących na poziomie licencjackim, aż 3222926 ukończyło kurs short cycle, a 3585940 tzw. „normal cycle”. Oznacza to, że krótkie cykle kształcenia są nie tylko uznawane, ale także muszą być efektywne jeśli chodzi o lokalny rynek (OECD, 2017).

Rewolucja naukowa to także zwiększenie roli kursów odpowiadających standardom europejskim i amerykańskim. W tym trybie kształci się niemal połowa studentów. Jednocześnie jednak, ChRL sukcesywnie przekształca te kursy w kierunku postaci takiej, jaka jest na Zachodzie, gdyż ,short cycle tertiary" nie jest uważany na zachodzie jako wykształcenie wyższe. Ujednolicenie cyklów kształcenia staje się zatem dla Chin niezbędnym wymogiem w strategii rozwojowej systemu kształcenia, bez którego procesy internacjonalizacyjne nie będą kompatybilne z systemem uczelnianym Świata Zachodniego.

Chińska sfera szkolnictwa wyższego posiada olbrzymi potencjał rozwojowy w kontekście danych demograficznych. W grupie 20-latków tylko $26 \%$ stanowią studenci. Dla porównania, w Polsce wskaźnik ten wynosi 43, w Korei aż 68, w Wielkiej Brytanii 40 (OECD, 2017, tab. C1.2, s. 293). Inwestycje w tę sferę polityki publicznej pokazują, że tendencja ta ma charakter wzrostowy, a chińskie uczelnie przygotowują się do absorbcji większej ilości studentów. Zmiana kultury edukacyjnej do 1999 roku promującej kształcenie oraz otwierającej się na studentów przynosi efekty w postaci stabilnego wzrostu słuchaczy. Nie będzie zaskoczeniem, jeśli chińskie uczelnie zwiększą ilość przyjmowanych studentów do 10 milionów do 2020. Szacuje się, że liczba wszystkich studentów w Chinach (obejmująca również short cycle tertiary) wynosi ponad 36 milionów³.

${ }^{3}$ Nie poruszamy w tym miejscu zagadnień powiązanych, takich jak system chińskiej matury (gaokao). Innym problemem był wprowadzony system restrykcyjnego meldunku w 1958 roku (hukou), który od roku 2014 jest reformowany: system ten opierał się wcześniej na podziale meldunkowym na miasto i wieś, który obecnie zostaje przekształcany, tak aby umożliwiać migrację do ośrodków miejskich. W kwestii liberalizacji hukou patrz Xiaobo, 2016. 
Kolejną charakterystyką rewolucji szkolnictwa wyższego jest wzrost dynamiki nakładów na edukację w Chinach - są to dane zbiorcze dotyczące wszystkich szczebli edukacyjnych między 2008-2013 rokiem. Według danych OECD zmiana wydatków publicznych, jako odsetek PKB kierowany na instytucje edukacyjne między latami 2008-2013 zostaje określony jako 154, przyjmując, 100 za punkt wyjścia w 2008 r., (OECD, 2017, fig. B2.4, s. 208). Jest to znaczący wzrost nakładów na dziedzinę edukacji, który de facto potwierdza tezę o wysunięciu polityki edukacyjnej jako priorytetu rozwojowego.

Naszkicowanie wybranych cech obrazu szkolnictwa wyższego Państwa Środka nie jest zadaniem łatwym, gdyż wiele danych o ChRL, prowadzonych w międzynarodowych badaniach porównawczych, np. OECD, nie jest możliwych do uzyskania. W tym znaczeniu obraz ten pozostaje szczątkowy.

\section{Szkolnictwo wyższe i dyplomacja naukowa jako element soft power}

J. Nye (2007) określa soft power jako kutrowo-polityczną siłę przyciagania, która zamiast użycia argumentu konfrontacji i siły polega na przekonaniu do siebie partnera. W tej koncepcji procesy globalizacyjne opierają się nie tyle na konflikcie czy konkurencyjności, ale na współpracy. Kluczową rolę w soft power odgrywa sfera kulturowa. Określając soft power Nye (2007) wskazuje na przykłady działań m.in. ustanowienia wyspecjalizowanych agend, natomiast na poziomie środków wskazuje na kulturę, wartości i instytucje, natomiast na poziomie politycznym wskazuje na dyplomację publiczną (Nye, 2007, s. 62). W określeniu soft power można by użyć sformułowań takich, jak „wzmacnianie atrakcyjności” danego państwa, „kulturowe przyciaganie”, czy też „aksjologiczne uwspólnienie”, będące uzupełnieniem dla „twardej” polityki. Soft power podkreśla znaczenie budowania pokojowych relacji pomiędzy państwami.

Można by powiedzieć, że soft power działa jak zasłona dymna dla realnych interesów i występowała już ona w przeszłości, np. w dyplomacji publicznej byłego ZSRR. W okresie zimnej wojny takie narzędzie było używane przez ZSRR i kraje satelickie, „zmiękczające" wizerunek totalitarnych reżymów, mającej najczęściej na celu budowanie kamuflażu dla Realpolitik oraz wzmacnianiu propagandy, w którą angażowano intelektualistów z wolnego świata. We współczesnym znaczeniu, soft power staje się wsparciem dla nowych funkcjonalności, np. współpracy międzyinstytucjonalnej, co w przypadku dyplomacji naukowej ma szczególne znaczenie.

W strategii soft power odniesionej do uniwersytetów, celem jest zbudowanie komunikacji kulturowej i normatywnej, uwspólnianie wartości i działań oraz wytwarzanie warunków do dalszej współpracy. Wskazując na role uniwersytetów w tym procesie, ważną rolę odgrywają programy internacjonalizacyjne. W USA taką rolę spełnia Fulbright, przyciagający nie tylko naukowców, ale także przyszłych liderów i aktorów zmiany, którzy będą współpracowali z rządem USA (taką rolę odgrywa np. Kennedy Institute na Harwardzie), a w Niemczech, rolę promocji kulturowej odgrywają Instytuty Goethego. Soft power bazuje zatem na założeniu politycznym, że kultura spełnia istotną rolę w procesie polityki międzynarodowej, w wymiarze długofalowym. Należy zauważyć, 
że kultura jest transmitowana także przez międzynarodową politykę szkolnictwa wyższego. Zenderowski (2010, s. 129) pokazuje na dwie możliwe perspektywy ujęcia jej roli: kultura może być determinantem działań politycznych lub może stanowić pochodną tych działań. W kontekście soft power można mówić raczej o drugim wymiarze, kultura jest przyporządkowana celom politycznym. Hartig $(2016$, s. 6) podkreśla, że soft power w polityce międzynarodowej adresowany jest w pierwszym rzędzie do aktorów niepolitycznych (takich jak „elity przekazu symbolicznego”, tacy jak dziennikarze, naukowcy itp.), a finalnym celem ma być wzmocnienie bilateralnej współpracy. Miłoszewska i Potocki $(2010$, s. 5) wskazują na psychologiczną stronę procesu wprowadzania soft power: kreowanie wizerunku, kształtowanie opinii innych, wzbudzanie emocji i wreszcie wywieranie wpływu. W tym kontekście szkolnictwo wyższe może odegrać następujące role w kształtowaniu soft power:

- dyplomacja naukowa pozwala na zebranie informacji o trendach, priorytetach czy rozwiązaniach stosowanych w danym systemie szkolnictwa wyższego;

- stosowany przez uczelnie wyższe soft power buduje kapitał kulturowy w państwie partnerskim, w postaci familiaryzacji danej kultury oraz podnoszenia wiedzy o niej. Jednocześnie ułatwia on dotarcie do grupy przygotowującej się dopiero do podjęcia kariery zawodowej oraz elit kształtujących społeczeństwo;

- narzędzie to pozwala na implementację i współtworzenie narracji kulturowych oraz wpływa na normatywne interpretacje historii, jak i bieżących zdarzeń politycznych;

- przyczynia się do budowania zarówno sieci współpracowników, ale także agentów wpływu własnej polityki;

- ułatwia na poziomie operacyjnym uruchomienie bilateralnych programów współpracy oraz negocjacji, wzmacnia procesy poszukiwania nowych funkcjonalności.

W raporcie A Soft Power 30. A Global Ranking of Soft Power (2017, s. 43), chińska strategia jest określana następująco: „Chiński soft power rozpoczęła się wraz z organizacją Igrzysk Olimpijskich w Pekinie w 2008 r. oraz World Expo 2010 w Szanghaju. Od tamtej pory rząd zainwestował dziesiątki miliardów dolarów w soft power, rozwijając agencję prasową Xinnhua, ustanawiając setki Instytutów Konfucjusza na sześciu kontynentach [...]. W czasach, gdy wiele krajów ogranicza wydatki na takie instytucje i inicjatywy, Chiny parząc przyszłościowo, rozwijają zasoby swojej soft power". I chociaż Chiny zajmują w tym rankingu dopiero 28 miejsce, to jednak nakłady na ten cel spowodują wzrost skuteczności chińskiej soft power w kolejnych latach: dowodem na skuteczność jest otwieranie kolejnych instytutów Konfucjusza, czy też współpracy pomiędzy chińskimi $\mathrm{i}$ - w tym interesującym nas przypadku - europejskimi uczelniami.

Wśród narzędzi oddziaływania w chińskiej polityce międzynarodowej znajdują się kulturalne i naukowe. M. Tomaszewska, wskazując na te narzędzia, pierwsze znaczenie daje gospodarczym, jednak szeroko pojęte „psychospołeczne”, w tym naukowe wymienia na równi ze wsparciem ekspansji chińskich firm, budową sieci korporacji, czy też utrzymywaniem potęgi militarnej: „Chiny wykorzystują również instrumenty psychospołeczne, takie jak promocja kultury oraz nauki. Narzędzia te służą budowaniu prestiżu i kształtowaniu korzystnego wizerunku państwa na scenie międzynarodowej. Dzięki takim działaniom Chiny dążą do zjednania sobie innych społeczeństw oraz tworzenia warunków umożliwiających wywieranie wpływu politycznego" (Tomaszewska, 2015, s. 55). 


\section{Chińskie szkolnictwo wyższe narzędziem dyplomatycznym wobec Unii Europejskiej}

W chińskiej strategii ujawnia się nowe założenie epistemologiczne, w którym przyjmuje się, że to klasa kreatywna będzie współtworzyć sukces ekonomiczny Chin, a jej środowiskiem będą uniwersytety i ośrodki badawcze: innymi słowy, oparcie rozwoju nastąpi poprzez procesy kształcenia oraz generowania badań, gdzie instytucje uniwersytetu będą odgrywały kluczową rolę. Chcąc zatem zbudować własne silne zaplecze uczelniane, w chińskiej polityce szkolnictwa wyższego widać wyraźną zmianę przechodzenia z „kultury copycat", do budowania własnych ośrodków wytwarzania wiedzy i innowacji. Temu głównie służy rosnący udział studentów chińskich w Europie ${ }^{4}$. Zakłada się, że rozwój ekonomiczny wykorzystujący wysokozaawansowane technologie będzie musiał być generowany także przez uczelnie wyższe. Uczelnie Unii Europejskiej, ku którym zmierza dyplomacja naukowa ChRL, wpisują się w ten plan przynajmniej z następujących powodów: 1) europejskie uczelnie dysponują doskonałością badawcza, odpowiednim zapleczem infrastrukturalnym pozwalającym w przyszłości wspomóc działanie uczelni w Chinach; 2) są przewidywalnym i wiarygodnym partnerem, co dla ChRL ma szczególne znaczenie m.in. po ochłodzeniu stosunków z USA po 2016 roku; 3) reformy szkolnictwa wyższego w UE - przede wszystkim implementacja systemu bolońskiego - są cennym doświadczeniem oraz zasobem dobrych praktyk dla Chin, które znajdują się w obliczu reformy.

Na uczelniach chińskich rośnie zainteresowanie Europą oraz wykorzystaniem istniejących mechanizmów współpracy z UE. D. Bingran, wskazując na obszary problemowe adresowane przez ChRL do uczelni europejskich, potwierdza hipotezę o sprzężeniu szkolnictwa wyższego z międzynarodowym rozwojem gospodarczym: „W ostatnich latach rośnie trend studiów prawniczych. W tym czasie pojawiło się kilka istotnych studiów odnoszących się do zagadnień prawa UE oraz ładu prawnego, prawa rynku wewnętrznego, prawa konkurencji, prawa bankowego, prawa podatkowego, prawa środowiskowego oraz prawa administracyjnego, niemała część studiów dotyczyła kwestii prawno-handlowych w relacji Chiny-UE" (Bingran, 2008, s. 110). Według jego badań aż w 598 chińskich czasopismach pojawiały się teksty dot. problematyki Unii Europejskiej, „co może oznaczać, że przyjemniej jakieś 1200000 osób w Chinach dowiedziało się czegoś o Unii Europejskiej w stylu akademickim" (Bingran, 2008, s. 111). Autor zauważa również, że w chwili obecnej w Chinach przy kilkudziesięciu uczelniach funkcjonują centra, programy studiów lub badań oraz bilateralnych programów między UE a Chinami (Bingran, 2008, s. 111-112).

Chiny aktywnie wykorzystują możliwości współpracy na poziomie uczelnianym, korzystając z mechanizmów unijnych. Współpracę z Chinami w realizacji wspólnych działań badawczych określa strategiczna agenda rozwoju podpisana z Unią Europejską (Komisja Europejska, 2015). Wypunktowane się w niej priorytety badawcze to: nauki o żywności, rolnictwo, biotechnologia, zrównoważona urbanizacja, awiacja, nauki o wodzie, zdrowiu, ITC oraz energii odnawialnych. W dokumencie tym pojawia się także postulat dążenia do społecznej spójności, gdzie jak wiadomo uczelnie wyższe odgrywają znaczącą rolę cywilną. W tym miejscu należy wspomnieć o wykorzystaniu przez ChRL mechanizmów unijnych w procesach internacjonalizacji chińskiego szkolnictwa wyż-

${ }^{4}$ W 2014 roku liczba studentów z Chin w Wielkiej Brytanii przekraczała liczbę studentów ze wszystkich państw UE: na 58810 Chińczyków, przypadało 57190 studentów z UE (Gillman, 2015). 
szego. Wymieniając skrótowo wykorzystanie wybranych mechanizmów: między 2014 a 2016 rokiem 13 jednostek uniwersyteckich brało i bierze udział w programie Jean Monnet. Uruchomionych jest ok. 70 kursów magisterskich kończących się wspólnym dyplomem z uczelniami z ChRL oraz UE. Chiny, korzystając z tych mechanizmów, dążą przede wszystkim do uzyskania doskonałości oraz poszerzenia jakości kształcenia w ich ofercie. Oczywiście, na skalę Państwa Środka oddziaływanie to pozostaje minimalne, jednak należy mieć na uwadze, że w Chinach procesy internacjonalizacji są jeszcze w budowie. Warto w tym miejscu zauważyć, że centra badań nad Unią Europejską są nie tyle propozycją badań europeistycznych, ile punktem odniesienia do relacji Chiny-EU oraz możliwości ich wykorzystania przez uczelnie Państwa Środka.

Chińska „rewolucja naukowa” nastawiona jest na osiagnięcie jeszcze jednego celu, jakim jest wejście uczelni Chin do światowej ligi uniwersyteckiej. Znaczną rolę odgrywa w tym przypadku program World Class 2.0. Parr (2017) określający tę strategię następująco: , ,...] World Class 2.0 została ujawniona dwa lata temu. Cel jest prosty: uzyskać pozycję sześciu uniwersytetów między uczelniami o światowym znaczeniu do 2020 roku oraz uzyskać pozycję kilku uczelni w 165 najlepszych uczelni świata do roku 2030". Strategia ta ma doprowadzić do zerwania z wizerunkiem Chin jako importera wiedzy i technologii. Biorąc pod uwagę aktualne międzynarodowe rankingi - w rankingu US News 27 chińskich uczelni znajduje się w Top 500, natomiast QS Ranking 41 uczelni z ChRL osiagnęło pozycję w Top 500.

Realizacja „rewolucji instytucji wiedzy” nie ogranicza się do samych uniwersytetów, równolegle do niej powstała strategia „Made in China 2015”, która ma wyzwolić potencjał innowacyjny w Państwie Środka: „Plan wzywa chińskie firmy do podjęcia wysiłku na poziomie międzynarodowym, a tym samym poprzez zaznajomienie się z kulturami i rynkami zagranicznymi” (Kennedy, 2017).

Drogą to tego celu jest ekspansja międzynarodowa chińskiego szkolnictwa wyższego i w tym celu władze ChRL używają właśnie soft power: ,Soft power może być »wysoka«, odniesiona do elit oraz »niska« odniesiona do szerszej publiki. Chociaż soft power wychodzi od aktorów rządowych i pozarządowych, można zidentyfikować narzędzia strategiczne oraz polityczne świadomie używane przez Pekin do zdynamizowania soft power, a przez to do poszerzenia legitymizacji oraz wyzwolenia superwładzy. Innowacyjna i systematycznie zaplanowana przez Pekin soft power pociaga za sobą dwutorową strategię: goszczenia międzynarodowych studentów oraz otwieranie w świecie Instytutów Konfucjusza” (Yang, 2010, s. 25).

Według autora, ChRL wydaje rokrocznie około 25 milionów dolarów przeznaczonych na wzmocnienie pozycji języka mandaryńskiego i kultury chińskiej w świecie. Oczywiście Instytuty Konfucjusza nie tylko realizują misję językową, co więcej zasadniczy cel tych instytucji jest zupełnie inny. Według D. Bingrana (2007, s. 262-264), z punktu widzenia Chin, użycie Instytutów Konfucjusza (tzw. „Kongzhi College”) służy przede wszystkim do poprowadzenia wzajemnego dialogu i poznania. Autor podaje, że Instytuty służą promocji kulturowej bazy, poprzez promocję języka, czy też prezentacje tłumaczeń aktualnej literatury pięknej i akademickiej powstającej w Chinach. Mają one także za zadanie ocieplić wizerunek Chin.

Instytuty Konfucjusza budowane są według metody „marketingu bezpośredniego” czyli małe ośrodki, funkcjonujące zarówno przy wielkich uczelniach (jak np. London School 
of Economics), jak i peryferyjnych. Instytuty Konfucjusza zorientowane są na zbudowanie lokalnego oddziaływania, a ich zadania skupiają się na transmisji kultury języka mandaryńskiego. Pomysł na ich działanie różni się np. od niemieckich Instytutów Goethego, powstają one w otoczeniu danej uczelni za granicą - i zawsze przy współpracy z uczelnią chińską. Daje to sposobność rozwinięcia narzędzi internacjonalizacyjnych tym uczelniom, przede wszystkim utrzymuje je w stałym kontakcie z uczelnią partnerską $\mathrm{i}$ jej otoczeniem. O ile pierwszym celem instytutów jest przybliżanie kultury, o tyle pełnią one rolę HUB-ów wiedzy między partnerami lokalnymi a uczelniami z Państwa Środka. Jest to rozwiązanie niezwykle sprawne: dociera bezpośrednio - używając sformułowania R. Floridy - do „klasy kreatywnej”, do większości odbiorców kształtujących swoją przyszłą drogę zawodowa, ale jednocześnie działając przy uniwersytetach posiadają profesjonalne zaplecze badawcze i edukacyjne. Wartością dodaną licznie rozlokowanych ośrodków na wszystkich kontynentach świata jest możliwość przygotowania własnych analiz dotyczących potencjału i priorytetów badawczych uczelni danego państwa, wiedza ta przekłada się na wsparcie dla decyzji strategicznych, np. sformułowania adekwatnej strategii dotyczącej współpracy gospodarczej, ale także zbierania danych. Organizacja Instytutów Konfucjusza opiera się na umowach dwustronnych między chińską centralą tych instytutów, a poszczególnymi uczelniami. Chińska strona, choć nie w każdym przypadku, opłaca wicedyrektora instytutu oraz część zadań danej jednostki. Instytut ma obowiązek uruchomić kurs języka mandaryńskiego oraz oferty kulturalnej. Dokonuje również certyfikacji znajomości języka mandaryńskiego, co wzmacnia ich rolę jako lokalnej „,bramy” do kultury chińskiej. Jednocześnie jednak uczelnia partnerska dla danego instytutu ma możliwość rozwijania współpracy - i to właśnie stanowi najistotniejszy punkt pracy tych instytutów. Instytuty Konfucjusza pełniłyby funkcje kontaktowe pomiędzy uczelniami w danym państwie a uczelniami w Chinach. Zadanie takie osiagnięte poprzez stopniowe wchodzenie w tkankę uczelni zagranicznych pozwoliłoby na zbudowanie nie tylko sieci współpracy i wpływu, ale także na pozyskiwanie informacji o priorytetowych badaniach i prowadzonych pracach technologicznych. W takim scenariuszu przekazywana wiedza wzmacniałaby potencjał nie tylko uczelni Państwa Środka. Instytuty Konfucjusza staną się instytucjami komunikacji zmian w strategii Chin wobec uczelni europejskich: jedną z nich jest przeniesienie nacisku ze studiów o charakterze językowo-kulturowym, na współdziałania skupiające się na ekonomii oraz technologii.

Chińskie uczelnie znajdują się w zainteresowaniu europejskich stowarzyszeń uczelni Unii Europejskiej, takich jak UNICA, czy Santander Group. Program współpracy z Chinami, UNICA - LEAD jest jednym z najważniejszych skupia bowiem czołowe uczelnie stolic europejskich, łącząc je z uniwersytetami ChRL - niekoniecznie osadzonych w Pekinie. Przykładowo, grupa uczelni skupiona wokół Santander Group uruchomiła Think Tank for China eksplorujący możliwości ułatwień administracyjnych przy współpracy z uczelniami Państwa Środka. W działaniach obu instytucji ujawnia się dążenie do poszerzenia możliwości instytucyjnego oddziaływania, co pokazuje, że Chinom udaje się wpisać w nową falę zainteresowania współpracą ze strony uczelni z państw UE ${ }^{5}$. Można przyjąć, że pierwszą falą obecności Chin na uczelniach wyższych Europy było zaintere-

${ }^{5}$ Przykładem jest strategia rozwoju np. King’s College w Londynie, gdzie priorytetem jest sieć globalnych powiązań oraz zbudowanie „wspólnoty uczących się, w której studenci i wykładowcy będą współpracować i łączyć się między dyscyplinami dla zmiany świata” (Lima, 2017). 
sowanie w kontekście studiów sinologicznych i praktycznej nauki języka mandaryńskiego. Obecnie, co już zostało nadmienione wcześniej, celem jest nie tylko promocja kultury i języka chińskiego, ale zbudowanie relacji między dyscyplinami oraz badaczami, natomiast $\mathrm{w}$ wymiarze studiów będzie to zainteresowanie dziedzinami przekraczającymi kwestie ekonomiczne, np. stosunkami gospodarczymi.

\section{Chińska dyplomacja naukowa w kontekście Polski}

W chwili obecnej widać rosnące zainteresowanie współpracą z Chińską Republiką Ludową na poziomie rządowym, w tym także w polityce szkolnictwa wyższego. $\mathrm{Na}$ poziomie polityki szkolnictwa wyższego polskie uczelnie uruchamiają programy współpracy $^{6}$. W ciagu ostatnich kilku lat przy polskich uczelniach między innymi na UWr, UAM, UJ, Politechnice Opolskiej, czy UG powstały Instytuty Konfucjusza. Z pewnością jest to inicjatywa bardzo aktywnie przybliżająca kulturę Państwa Środka, o czym świadczy zainteresowanie studentów oraz rozwój oferty tych ośrodków. Należy jednak postawić sprawę, że współpraca z Chinami, poza kilkoma wyjątkami, sprowadza się w znacznej mierze w Polsce do studiów kulturowych. Tymczasem strategia chińska jest obecnie odmienna: ChRL dąży do sprzężenia nie tylko studiów w zakresie kulturowym, lecz w wymiarze praktycznym, otwierając się na nowe przedsięwzięcia edukacyjne. Jest to ważne wyzwanie, które powinno zostać zauważone przez decydentów zajmujących się dyplomacją naukową w Polsce.

Nie można zapomnieć w tym miejscu o kwestii wątków wolnościowych. W Polskiej tradycji uniwersytety wiązały się z misją cywilna, wielu spośród dysydentów było profesorami uniwersyteckimi w okresie PRL. Z tego względu wątek swobód obywatelskich może być ważny w odpowiedzi na ekspansję chińskiej dyplomacji naukowej. Warto zwrócić uwagę, że sfera akademicka w Chinach jest miejscem nie tylko oficjalnej ideologii - co często się zarzuca - ale także względnej wolności wymiany poglądów. Władze Chin mają świadomość różnic aksjologicznych między światami Zachodu i Dalekiego Wschodu. Jakkolwiek, wymiana akademicka z Chinami daje możliwość kontaktu studentów ze światem wartości zachodnich, przede wszystkim aksjologii budującej życie publiczne.

Z pewnością szansą dla polskich uczelni jest zagospodarowanie części rynku edukacyjnego przez chińskich studentów. W chwili obecnej poziom polskiej internacjonalizacji należy do najniższych w Unii Europejskiej i wynosi zaledwie 5\% (stosunek liczby studentów zagranicznych do studentów polskich). Wykorzystanie narzędzi ustawy Prawo o szkolnictwie wyższym (Ustawa, 2005) pozwala na tworzenie wspólnych studiów i dyplomów z uczelniami innych państw, także warunki legalne do współpracy istnieją. Kolejnym elementem możliwości dla polskich uczelni jest wzmocnienie płatnymi studiami (taką strategię stosuje np. Uniwersytet SWPS), polskie uczelnie mają szansę na zagospodarowanie chińskich studentów, m.in. konkurencyjnymi w stosunku do Zachodu kosztami życia. Wzrost liczby studentów otwiera przed polską polityką szkolnictwa

${ }^{6}$ Przykładem może być współpraca Centrum Technologii UW z firmą Huawei, czy też program studiów w zakresie nowych technologii uruchomiony przez Politechnikę Rzeszowską z Uniwersytetem Guangxi. 
wyższego nowe możliwości: biorąc pod uwage prognozowane przekroczenie liczby chińskich studentów powyżej 8 milionów, to przyjmując tylko 5\% jako odsetek potencjalnie zinternacjonalizowanych, daje liczbę ok. 400 tysięcy do zagospodarowania przez zagraniczne uczelnie.

Warto na koniec podrozdziału nadmienić kwestię relacji chińskiej dyplomacji naukowej do programów międzynarodowych. Jedną z nich jest idea Nowego Jedwabnego Szlaku, w efekcie której pojawiła się inicjatywa University Alliance of the New Silk Road. Skupia ona uczelnie kilkunastu państw na potencjalnym nowym jedwabnym szlaku. Oficjalnie jest to organizacja pozarządowa, lecz realnie jej celem jest umocnienie kooperacji z chińskimi uczelniami ${ }^{7}$. Niezależnie od realności powstania Nowego Jedwabnego Szlaku idea daje szanse na wyzwolenie nowych potencjałów rozwojowych dla uczelni (XJTU News, 2015). Utworzenie związku uczelni związanych z Jedwabnym Szlakiem pozwala na zbudowanie zupełnie nowej konfiguracji współpracy uczelni państw UE a Chinami. Chociaż idea nowego Jedwabnego Szlaku znajduje się dopiero na poziomie planów politycznych, to Chiny już teraz wykorzystują ją w swojej dyplomacji naukowej. Jeszcze inną polską odpowiedź na tę inicjatywę dała Politechnika Poznańska, która zorganizowała Centrum Badawcze nad Nowym Jedwabnym Szlakiem, na tę chwilę pełni ono rolę transferową między uczelniami partnerskimi. Innymi słowy, propozycja zbudowania Nowego Jedwabnego Szlaku otwiera zupełnie nowe możliwości umiędzynarodowienia uniwersytetów i otwarcia nowej geopolitycznej konfiguracji współpracy między państwami leżącymi na jego trasie.

Barierą w rozwoju relacji ze stroną chińską bynajmniej nie pozostaje bierność uczelni, przeciwnie, oddolnych inicjatyw jest wiele. W roku 2017 powstało konsorcjum uczelni polsko-chińskich, w skład którego wchodzą 23 uczelnie z Polski i ChRL, konsorcjum łączy głównie uczelnie techniczne po polskiej stronie (liderem jest Politechnika Opolska), natomiast po stronie chińskiej, są to uczelnie z ponad 30 milionowego miasta Chongqing. Kwestią wymagającą rozwiązania jest przygotowanie krajowej strategii odpowiadającej na ten projekt oraz ustanawiającej komunikację pomiędzy interesariuszami szkolnictwa wyższego oraz gospodarki. Brak spójności oraz jednolitej polityki ze strony rządu rozprasza potencjał współpracy między uczelniami, natomiast podpisanie umów z poziomu konsorcjum uczelni osłabia znowuż ewentualną pozycję negocjacyjną państwa w sytuacji pojawienia się ewentualnych rozbieżności, lub sporów natury politycznej.

Poważnym deficytem polskiej polityki szkolnictwa wyżzzego jest brak ustalonych priorytetów badawczych (czy też priorytetowych dziedzin wiedzy), co znacznie osłabia budowanie polskiej strategii międzynarodowej. Nie wiadomo, które z państw są kluczowymi partnerami dla polskich uczelni, lub które miałyby się stać państwami o ściślejszej współpracy naukowej. Wcześniej spośród krajów Azji wymieniano np. Kazachstan, jednak dynamika rozwoju Chin powinna pojawić się w szczególnej uwadze polskiej dyplomacji naukowej. Wysokorozwinięte państwa Unii Europejskiej dysponują zarówno celowymi programami współpracy (np. w Niemczech Humboldt Stiftung, czy francuski Campus France), które na poziomie operacyjnym pozwalają łączyć partnerów oraz wytwarzać produkty edukacyjno-badawcze, ale także wyspecjalizowaną kadrą do obsługi takiej współpracy. Państwa zachodnie uruchomiły również wspólnie z Chinami studia

${ }^{7}$ ChRL systemowo wdraża Instytuty Konfucjusza we współpracy z uczelniami w proces tworzenia Nowego Jedwabnego Szlaku, m.in w Niemczech (zob. Gaspers, 2017). 
w zaawansowanych technologicznie dziedzinach nauki (na zasadzie podwójnych dyplomów). Wreszcie ogromną rolę spełniałyby kontakty polskich uczelni z gospodarką, gdzie uczelnie pełniłyby rolę wsparcia potencjału ekonomicznego państwa, przedłużonej ręki dla realizacji interesów gospodarczych.

\section{Zakończenie}

Polityka szkolnictwa wyższego Chińskiej Republiki Ludowej stała się elementem dyplomacji naukowej oraz kulturalnej, jak i składową planu długofalowego rozwoju gospodarczego Państwa Środka. Chiny konsekwentnie realizują ambitne cele, w tym wprowadzenie kilkunastu uczelni do grupy światowych liderów nauki, ale także zbudowanie nowej klasy kreatywnej, elit wytwarzających technologiczne innowacje. Uczelnie znajdujące się w Unii Europejskiej są najbardziej atrakcyjnym celem dla ChRL, nie tylko z powodu ochłodzenia stosunków z USA po 2016 roku, ale także z powodu wdrożonych systemów administrowania wiedzą jakością uczelni oraz przystosowania się do zmian. Jednocześnie jednak, atrakcyjność tych uczelni wynika z ich naukowej doskonałości. Chiny zdają sobie sprawę, że zbudowanie potencjału własnych uczelni wymaga zbudowania relacji z wysokorozwiniętymi uczelniami Świata Zachodniego, głównie w USA i w Europie. Realizacja tego celu odbywa się między innymi poprzez instrumenty, jakimi są Instytuty Konfucjusza, ale także oficjalne otwarcie się chińskich uczelni na Unię Europejską w ostatniej dekadzie. Uczelnie chińskie rozwijają studia europejskie, korzystają z unijnych programów, współpracują z europejskimi stowarzyszeniami uczelni. Instytuty Konfucjusza służą nie tylko wymianie akademickiej, ale także kulturalnej oraz podejmują tematy natury aksjologicznej.

Państwo Środka inwestuje olbrzymie środki finansowe na ten cel. Należy postawić pytanie, kto będzie ostatecznym beneficjentem programu Instytutów Konfucjusza? W oficjalnej linii dyplomacji naukowej ChRL, beneficjentami mają pozostać przede wszystkim uczelnie partnerskie oraz ich otoczenie. Można jednak przychylić się do konstatacji: ,,[...] Realnym wygranym mogą być chińskie uniwersytety, które rozwiną swoje kontakty i wymianę z zagranicznymi instytucjami. Jako, że Chiny aspirują by być „,społeczeństwem innowacji” oraz wzmacniają swoje naukowe możliwości, zwiększają komunikację i wymianę z zagranicznymi uczonymi afiliowanymi przez Instytut Konfucjusza, mogą one stać się potężnym beneficjentem, szczególnie w tych państwach, w których otwarcie na świat pozostaje siłą napędową rozwoju ekonomicznego" (Paradise, 2009, s. 665). Uwaga ta nie jest pozbawiona racji, autor wskazuje także na Realpolitik, gdzie ostatecznym celem soft power pozostaje wzmocnienie potencjału - w tym przypadku ChRL. Hartig przytacza w tej kwestii opinię Yan Xuetong'a: „Prawdopodobnie najbardziej znaczącym oponentem tej wizji [tj. soft power - CK] pozostaje badacz stosunków międzynarodowych Yan Xuetong, który mocno argumentuje, że centralnym punktem soft power nie jest siła kulturowa, lecz siła polityczna" (Hartig, 2016, s. 65).

Przyjmując uwagi J. F. Paradise'a oraz realistyczny pogląd Yan Xuetong'a odwołujący się do realnej siły stojącej za soft power, w tym także wykorzystującej narzędzia polityki szkolnictwa wyższego można postawić wniosek, że najlepszym zabezpieczeniem własnych interesów będzie zbudowanie priorytetów polskiej polityki szkolnictwa 
wyższego oraz zdefiniowanie własnych celów i korzyści z zakładanej współpracy. Projektując strategie umiędzynarodowienia należy mieć na uwadze, że rynek szkolnictwa wyższego stał się obecnie rynkiem globalnym, a zaawansowane powiązania ekonomiczne w sposób naturalny pobudzają uniwersytety do zaangażowania się w procesy internacjonalizujące programy studiów i badań.

\section{Bibliografia}

Bingran D. (2007), Promoting mutual understanding, w: China-EU. A common future, red. S. Crossick, E. Reuter, World Scientific, New Jersey.

Bingran D. (2008), European studies in China, w: China-Europe Relations: Perceptions, Policies and Prospects, red. D. Shambaugh, E, Sandschneider, Z. Hong, Routledge, London.

Hartig F. (2016), Chinese Public Diplomacy. The rise of the Confucius Institute, Routledge, London.

Gaspers, J. (2017), Niemcy, w: Chiński projekt Nowego Jedwabnego Szlaku. Retoryka a rzeczywistość, red. K. Iwanek, O. Pietrewicz, ASW, Warszawa.

Glasser B., Murphy M. (2009), Soft Power with Chinese Characteristic, w: Chinese Soft Power and its Implication for the United States, red. C. MacGiffert, Center for Strategic and International Studies, Washington.

Gillman O. (2015), More Chinese students at UK universities than from the whole of the EU, „Dailymail", 16 stycznia.

Kennedy S. (2017), Made in China 2015, Center for Strategic and International Studies, Washington.

Komisja Europejska (2015), EU-China 2020 Strategic Agenda for Cooperation, Brussels.

Lima T. (2017), International partnership: what next? Perspective from a UK university, prezentacja, Kings College, London.

Miłoszewska D., Potocki R. (2010), Rola soft power w środowisku międzynarodowym, Repozytorium Uniwersytetu im. Adama Mickiewicza.

Ministerstwo Edukacji ChRL (2014), List of Chinese Colleges and Universities in 2014, http://en.moe. gov.cn/Resources/Directories/201506/t20150626_191383.html.

Ministerstwo Edukacji ChRL (2015), Number of Non-government schools by Types and Levels, http:// en.moe.gov.cn/Resources/Statistics/edu_stat_2015/2015_en01/201610/t20161012_284508. html.

Nye J. (2007), Soft power. Jak osiagnać sukces w polityce światowej, WAiP, Warszawa.

OECD (2017), Education at Glance 2016, Paris.

Paradise J. (2009), China and International Harmony: The Role of the Confucius Institutes in Bolstering Beijing's Soft Power, „Asian Survey”, nr 49/4.

Parr Ch. (2017), These universities have the best reputation worldwide, World Economic Forum, https:// www.weforum.org/agenda/2017/06/universities-best-reputation-china-times-higher-2017/.

Schulte B. (2012), Bildungssystem im Wandel: Elitenbildung, Ungleichheiten, Reformversuche, w: Country Report China, University of Lund, Lund.

A Soft Power 30. A Global Ranking of Soft Power (2017), USC Center on Public Diplomacy, Portland.

Sporek T. (2012), Analiza stosunków handlowych pomiędzy Chińska Republikq Ludowa a Uniq Europejska, „Studia Ekonomiczne”, nr 21.

Stapleton K. (2017), China now produces twice as many graduates a year as the USA, World Economic Forum, https://www.weforum.org/agenda/2017/04/higher-education-in-china-has-boomed-inthe-last-decade. 
Szwabe M. (2005), Rosnqce znaczenie Chin - wyzwanie dla Unii Europejskiej, „Wspólnoty Europejskie", nr 2(159).

Tomaszewska M. (2015), Od Mao Zedonga do Xi Jinpinga. Cechy, cele, kierunki i narzędzia zagranicznej polityki gospodarczej Chińskiej Republiki Ludowej, „Ekonomia Międzynarodowa”, nr 10.

Ustawa Prawo o szkolnictwie wyższym, Dz. U. 2005, Nr 164, poz. 1365.

Xiaobo Wu. (2016), Hukou reform under way in 29 regions across China, „China Daily”, http://www. chinadaily.com.cn/business/2016-04/29/content_24966027.htm.

XJTU News (2015), XJTU Initiated the University Alliance of the New Silk Road, http://en.xjtu.edu.cn/ info/1043/1706.htm.

Yang R. (2010), Soft power and higher education: an examination of China's Confucius Institutes, „Globalisation, Societies and Education”, nr 8/2.

Zenderowski R. (2010), Międzynarodowe stosunki kulturalne, PWN, Warszawa.

\title{
Higher education and scientific diplomacy as a soft power tool in the policy of the People's Republic of China towards the European Union
}

\begin{abstract}
Summary
Higher education policy is an element of soft power in the international politics of the PRC. This has become possible because, for two decades, universities in China have been developing and undergoing profound changes. PRC authorities have set ambitious goals for their universities, e.g. making some of the universities top higher education institutions worldwide. Universities in China are abandoning the "copy-paste" pattern, developing their own technological innovations, and consistently raising their position in international rankings. Development goals set for Chinese universities are connected with the global economic expansion of the PRC. The scientific diplomacy of China is primarily executed through the Confucius Institutes network. European Union universities are a strategic goal of this policy as they possess the resources, practices and customs China needs to strengthen its universities. The paper analyzes selected issues of employing higher education policy as a soft power in Chinese diplomacy.
\end{abstract}

Key words: universities in China, scientific diplomacy, soft power, EU, Polish higher education policy 
